\title{
Inverkar musiken i en reklamfilm på konsumenters uppfattning om produkten som annonseras? \\ - En fallstudie
}

\section{Inledning}

Dagens samhälle är fyllt av en mängd ljudbilder. Förutom musik som vi medvetet och självmant lyssnar på omringas vi varje dag av s.k. dold eller bakgrundsmusik i köpcentrum, matbutiker samt på arbetsplatsen. Då vi knäpper på TV:n förmedlas musik till oss via TV-program, filmer och reklamfilmer. Philip Tagg (1999a: 3) påpekar att musiken i TV står för mer än en fjärdedel av all musik vi hör.

TV-stationer världen över är idag till stor del finansierade med reklamintäkter. Då vi tittar på TV utsätts vi därför ofrivilligt för TV-reklamer. En undersökning gjord i Sverige visar att $88 \%$ av TV-reklamerna innehåller musik. (Bjurström \& Lilliestam 1993: 10, 34.) Om musiken används i så stor utsträckning i reklamfilmer måste den ha en funktion. Annars skulle inte reklambyråerna ägna så mycket tid och pengar till att välja ut och använda musik i reklamfilmerna. En stor del av musiken vi hör idag når oss alltså via TV-reklamer. Detta är en stor orsak till att jag valt att undersöka reklammusik och dess påverkan på konsumenten.

Då jag talat med människor om reklammusik visar det sig att de nog är medvetna om musiken i TV-reklamer. De refererar dock till välkända jinglar eller någon musikartist som man ser uppträda i reklamfilmen. De här formerna av reklammusik är starkt profilerade och deras uppgift är att uppmärksamma lyssnaren på musiken. Många reklamfilmer ackompanjeras däremot av musik som inte skall dra till sig tittarens uppmärksamhet, men ändå ge filmsekvensen en särskild stämning. Vid valet av den här typen av reklammusik är det ytterst viktigt att välja rätt musik för att den inte skall missleda tittaren eller ta bort uppmärksamheten från produkten som annonseras. (Lindqvist \& Paltschik 1987.)

Joanne Fellows (1998) kallar reklammusiken "en negligerad genre inom musikindustrin". I akademiska sammanhang har den hittills varit en ganska outforskad del 
av musikindustrin. De som arbetar med reklammusik, dvs. kompositörer och reklambyråfolk, lägger däremot ned mycket tid på att få fram den mest fördelaktiga musiken för en reklamfilm. Eftersom det inte finns så rikligt med litteratur som behandlar reklammusik har jag till stor del baserat min undersökning på tidigare gjord forskning inom filmmusik.

Den forskning som gjorts om reklammusik har till stor del handlat om hur väl musiken passar in i reklamfilmen, hur bra atmosfär den ger åt reklamfilmen och hur bra den passar till produkten som marknadsförs (Toivonen 1993; Cook 1994). Dessa undersökningar ger en god musikanalytisk bild av hur musik används i reklam, och hur den byggs upp runt bildbudskapet för att hjälpa till som betydelsebildare.

Undersökningar har även visat musikens roll som betydelsebildare i reklamfilmer. Jag har dock funderat över hur stor roll musiken spelar för konsumentens uppfattning om produkten som marknadsförs, om musiken i.o.m. att den ger en särskild stämning åt reklamfilmen kan påverka konsumentens bild av produkten som marknadsförs $\mathrm{i}$ reklamfilmen.

1. Kan musiken direkt påverka hur konsumenten uppfattar och värderar en produkt?

2. Hur mycket förändras konsumentens uppfattning av produkten om musiken byts ut mot en annan typ av musik?

Mitt mål är att klarlägga i vilken mån reklammusik påverkar hur konsumenten uppfattar en produkt som annonseras i en reklamfilm. Jag vill testa till vilken grad man kan ändra konsumentens uppfattning om en och samma produkt genom att byta ut musiken som ackompanjerar reklamfilmen. Jag har inte för avsikt att $\mathrm{i}$ detalj analysera de musikstycken jag använder. I stället använder jag mig av musikstilar, s.k. stereotyper, som enligt tidigare forskning har konstaterats ge särskild stämning till reklamfilmer och filmer.

Min studie går ut på att jag för en testgrupp visar en och samma bildsekvens av en reklamfilm tre gånger, $\mathrm{i}$ tur och ordning ackompanjerad av olika musikexempel. $\mathrm{Mu}-$ sikexemplen kan inte förväntas väcka exakt samma associationer hos testgruppen om de skulle ackompanjera en annan filmsekvens än den jag använder i min undersökning.

Undersökningen bygger på tio försökspersoners subjektiva åsikter. De kan inte förväntas representera ett helt lands befolkning, en viss samhällsklass eller åldersgrupp. Detta anser jag inte heller vara av stor betydelse. Jag vill endast testa hur musiken kan fungera som påverkare då den ackompanjerar en reklam, inte göra ett manifest över hur musiken påverkar alla TV-tittare oavsett vilken typ av reklamfilm den ackompanjerar.

I artikeln diskuterar jag tidvis tittarnas och tidvis konsumenternas uppfattning om en produkt som marknadsförs i TV-reklam. En tumregel är dock att alla TV-tittare skall uppfattas som potentiella kunder, dvs. konsumenter av den marknadsförda produkten. 


\section{Teori}

Musiken har, enligt Leonard B. Meyer (1956: 3), en emotionell påverkan vilken gör att lyssnaren känner olika sinnesstämningar som välbehag, lugn och energi beroende på musikens tempo, rytm eller harmonier. Långsam mollmusik väcker t.ex. ofta ledsamma eller sorgsna känslor hos lyssnaren medan snabb, rytmisk musik i dur ger känslor av energi och fartfylldhet (Toivonen 1993: 46).

De ovannämnda sinnesstämningarna är oftast känslor vi lärt oss sedan barn och är olika beroende på vilken musikkultur vi vuxit upp i (Meyer 1956: 10; Tagg 1994: 2). I fråga om musikaliska element som påverkar oss, kan man säga att vissa ses som universala och andra inte. Uppfattningen att durtonarter är glada och molltonarter sorgsna stämmer in i västerländsk musikkultur, medan t.ex. den indiska ragan inte använder sig av dur och moll för att förmedla sinnesstämningar. Ragan skapar däremot sinnesstämningar genom modal musik. Andra musikelement som t.ex. snabbt eller långsamt tempo kan däremot ses som mer universala påverkare. Ett ökande tempo verkar i de flesta musikkulturer upphetsande eller fartgivande, medan avtagande tempo i sin tur har en lugnande effekt.

Då vi lyssnar till ett stycke kan vi även göra associationer till utommusikaliska företeelser. Dessa är ofta mönster i musiken som vi lärt oss förknippa med olika kulturella sammanhang. I Sverige och Finland symboliserar t.ex. låten Den blomstertid nu kommer skolavslutning och en början på sommaren. En italienare skulle däremot inte göra samma associationer, eftersom låten inte har en plats i den italienska kulturen. På samma sätt kan man få en känsla av något finskt då man hör musik av Sibelius. Detta förutsätter dock att vi känner till Sibelius musik. (Toivonen 1993: 46.)

Dessa associationer (konnotationer) har vi lärt oss genom att vi hört ett stycke, en musikstil eller genre i ett visst kulturellt sammanhang och utifrån det kopplat ihop det med en viss handling, livsstil, kultur, ett visst område, folkslag etc. Många av dessa konnotationer till främmande kulturer har vi lärt oss göra via TV. Genom att se program från olika länder och kulturer där "typisk" musik spelats har vi lärt oss koppla ihop kultur, land och musikstil (Bjurström \& Lilliestam 1993: 30). Även om associationerna kan vara intersubjektiva, dvs. gemensamt uppfattade av flera människor, är de alltså i högsta grad beroende av vilken kultur man är uppvuxen $\mathrm{i}$.

Därtill kan människor göra olika associationer beroende på vilken ålder eller social grupp de tillhör. Technomusik kan t.ex. av ungdomar kopplas samman med fest och dans, medan äldre människor inte ser samma samband. Associationerna kan även vara "tidsbundna", dvs. att det associativa värdet av ett musikstycke eller en musikstil ändras med tiden. Låten Easy Rider av gruppen Steppenwolff symboliserade på 70-talet modernitet, "action" och fartfylldhet. Idag förknippas den snarare med nostalgi eller retro (Rönnberg 1996: 12).

Musik saknar enligt Bjurström denotationer, men ger å andra sidan upphov till en 
mängd konnotationer som kan förstärka eller specificera en bild. Musiken kan alltså tillsammans med en bild förstärka dess denotation. Om vi t.ex. ser en film eller ett fotografi av en solig strand när vi hör ett spanskt gitarrstycke gör vi automatiskt associationen att det är en strand på Spaniens solkust vi ser. (Bjurström \& Lilliestam 1993: 48.) Om det däremot är reggaemusik vi hör, är det antagligen en strand på Jamaica vi relaterar till. I det avseendet har musiken en avgörande roll för hur vi skall tolka en bild eller filmsekvens.

\section{Audiovisuell inlärningsprocess}

Då musiken förekommer i ett audiovisuellt samband förändras dock dessa betydelsebärande förmåga. En "vanlig" TV-tittare skulle med med stor sannolikhet inte kunna tyda budskapet i Richard Strauss Also sprach Zarathustra om han skulle lyssna till dem på en konsert. Då samma stycken däremot placeras in i film- eller TV-sammanhang som s.k. "osynlig" musik kan tittaren lätt koda musikens betydelse. Vi vet att ett crescendo oftast betyder att vi skall reagera på något laddat som händer i filmen och att en ensam dissonant fiol betyder att något hemskt ska hända. En melodi spelad i staccato betyder fart medan legato ger en känsla av lugn för filmens handling. Vi vet vad vissa musikaliska inslag betyder i en film. Philip Tagg (1979: 64) framhäver att det beror på den audiovisuella inlärningsprocessen vi genomgått genom att vi vuxit upp med TV och film samt de stereotyper av musik som används i dem. Vi har lärt oss koppla ihop viss musik med viss förväntad sinnesstämning.

Då musik används i film- och TV-sammanhang förmedlar den tillsammans med den bild vi ser en känsla eller betydelse (Bjurström \& Lilliestam 1993: 48). Den blir då en del av det kodningssystem som vi lärt oss genom att vi tidigare sett liknande musik ackompanjera motsvarande filmsekvenser. Detta system bygger på att "sound", orkestration, rytm, dynamik, tempo och motiv skall ha en särskild affektiv påverkan. På den grunden ger Tagg (1979: 64) exempel på stereotyper av musikgenrer som lyssnaren förväntas förknippa med vissa utommusikaliska sammanhang:

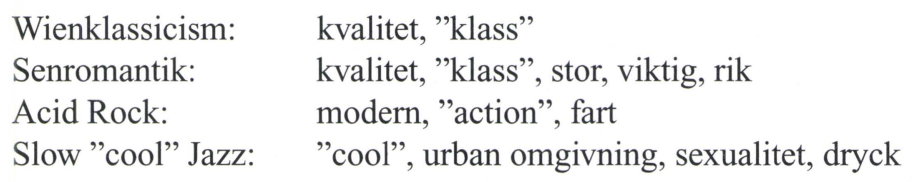

Musiken har faktiskt visat sig vara lättare att leva in sig i om man tillåts att placera in den i en (imaginär) filmsekvens. Då jag arbetat som musiklärare i årskurs sju, där eleverna är omkring 13 år gamla, har jag inlett varje lektion med att presentera ett känt klassiskt stycke. Eleverna skall då fundera över vilka känslor eller associationer som väcks då de lyssnar på stycket. Då jag frågat dem vilka känslor stycket väcker, dvs. 
om det är glatt, mäktigt, sorgset etc. har jag fått ganska korta svar som saknar inspiration. Då jag däremot frågat i vilket sammanhang stycket skulle förekomma i en film har fantasin börjat flöda; "mördaren smyger upp för trapporna", "dans på en äng" osv.

Stycket Also Sprach Zarathustra, uppfört i orkesterversion, placerade eleverna in $i$ en rymdfilm ${ }^{1}$ (var den även använts). Då jag spelade upp Eumir Deodatos version från år 1974, med ett funkigt trumm-, bas- och elpianokomp som grund, såg eleverna istället framför sig en spännande deckarscen eller en "cool" man som går på gatan etc. I det första fallet kan stycket jämföras med Taggs kategorisering av stereotyper av klassisk musik som betydelsebärare i TV- och filmproduktioner. Ungdomarna förknippade det stycket med något mäktigt, stort och rymd. En kommentar till orkesterversionen var: "sådan här musik är det ju alltid i rymdfilmer". Ungdomarna ansåg att musiken inte framkallade så starka känslor då den presenterades i ensam form. Då de däremot skulle placera in den i ett filmsammanhang bildade de sig genast en uppfattning om vilken typ av filmsekvens den skulle ackompanjera. Den audiovisuella inlärningsprocessen kan alltså konstateras bidra till att vi lättare refererar musik till särskilda utommusikaliska företeelser.

\section{Musik i TV-reklam}

Enligt David Huron (1989: 560-570) har musiken sex huvudsakliga funktioner i en reklamfilm. Den bör:

1) Vara underhållande och på så vis göra reklamen mer attraktiv. Han menar att musiken genom att vara underhållande väcker lyssnarens uppmärksamhet och därmed gör reklamen intressant för lyssnaren.

2) Ge en struktur åt reklamen. Den viktigaste strukturella funktionen är att skapa kontinuitet mellan snabbt bytande bildsekvenser. Då olika bilder och bildsekvenser i snabbt tempo byts och kopplas ihop, skulle de av tittarna ofta uppfattas som osammanhängande om inte musiken knöt ihop de olika delarna. En annan strukturell roll kan musiken ha genom att betona dramatiska ögonblick i reklamfilm. I det fallet använder man sig ofta av samma klichéer som i film- och TV-produktioner för att skapa särskilda affektiva känslor hos tittaren. Tittaren förbereds då på att något hemskt eller roligt skall hända, så att effekten av själva händelsen förstärks, eller åtminstone inte uppfattas "fel".

3) Förbättra chanserna att konsumenten skall komma ihåg produkten eller namnet på produkten. Produktnamnet eller brand name bakas ofta in i en kort musikslinga, s.k. jingel, och är på så vis lättare att komma ihåg av konsumenten. 
4) Sångtext kan användas för att överföra reklambudskapet då budskapet skulle kunna uppfattas naivt om det enbart lästes upp.

5) Rikta in reklamen på en målgrupp, dvs. targeting. Man kan med hjälp av musiken rikta in reklamen mot en specifik målgrupp då man använder en musikstil som attraherar den konsumentgrupp produkten är avsedd att marknadsföras till.

6) Skapa auktoritet, dvs. en välkänd musiker eller ett välkänt musikstycke hjälper till att ge produkten en viss status. Denna form av auktoritetsskapande har bl.a. använts av Pepsi då stjärnor som Michael Jackson, Madonna, Britney Spears etc. uppträtt i företagets TV-reklam. Denna form av auktoritetsbildande har samma effekt som då en tandläkare "råder" konsumenten att använda en viss tandkräm. Trots att popstjärnan inte har samma yrkeskompetens som läkaren har han eller hon ändå en status som ökar konsumentens förtroende för produkten.

Enligt en undersökning gjord bland reklambyråfolk i Finland anses musikens funktioner främst vara att skapa rätt stämning och förbättra minneseffekten av en reklam. Övriga betydande funktioner är att framhäva produktens namn, bildens budskap, ge filmen en viss rytm, fungera som bakgrund, underhålla och ge kontinuitet i reklamfilmen samt att göra produkten modern. Vidare framgår ur undersökningen att de anser att de tre viktigaste egenskaperna hos reklammusik att den spelas på rätt instrument, dvs. har rätt "sound", att den inte drar bort uppmärksamheten från produkten samt att den fungerar på kort tid, ca. fem sekunder. (Lindqvist \& Paltschik 1987: 6, 10).

Reklambyråfolket som Lindqvist och Paltschik intervjuat har alltså ganska långt samma åsikt som Huron. Skapa rätt stämning kan jämföras med Hurons påstående att musiken används för att betona särskilda ögonblick. Båda forskningarna visar att musiken skall ge kontinuitet i reklamfilm. Då Huron säger att musiken skall ge en struktur åt reklamen, och binda samman bildsekvenser etc. konstaterar Lindqvist och Paltschik att den skall ge filmen en viss rytm och fungera som bakgrund. Dessa egenskaper kan anses ge samma effekt åt reklamfilmen. Då musiken ger rytm åt reklamfilmen ger den även reklamfilmen en struktur. De delar även åsikten att musiken kan bidra till att förbättra minneseffekten av reklamen och att den kan användas för att framhäva produktens namn.

Vidare påpekar Lindqvist och Paltschik att musiken skall vara modern. Detta kan jämföras med Hurons påstående om targeting, dvs. att rikta sig till en viss konsumentgrupp. Då man valt ungdomar som konsumentgrupp är valet av modern musik naturligt. Om man däremot vill betona att produkten man marknadsför har många år bakom sig och därför är ett tryggt val, är det kanske säkrare att inte välja modern musik. Musikalisk targeting förutsätter delvis även att valet av musik har rätt "sound". Vikten av att man väljer rätt musik och rätt sound för att attrahera rätt målgrupp skall jag 
mer i detalj gå in på längre fram i min undersökning.

Lindqvist och Paltschik betonar att musiken inte skall dra bort uppmärksamheten från produkten (Lindqvist \& Paltschik 1987: 10). Det kan vara en ytterst viktig och väldigt känslig balansgång mellan att välja musik som förmedlar den känsla man vill framhäva i reklamfilmen och ändå inte överrösta den visuella delen av reklamfilmen och på så vis försvaga reklambudskapet.

\section{Anskaffning av reklammusik}

Anskaffning av reklammusik görs på tre sätt. Vid valet av musik till reklamer kan reklambyrån välja mellan 1) originalkompositioner 2) tidigare inspelad musik 3) Library Music, även kallad produktionsmusik. (Fellows 1998: 4.)

Det vanligaste tillvägagångssättet för anskaffning av musik till en reklamfilm är enligt Lindqvist \& Paltschik (1987: 9-10) att använda sig av originalmusik, även kallad specialkomponerad musik, dvs. anlita en kompositör som gör ett musikstycke skräddarsytt för just denna reklam. Deras undersökning gjord bland reklambyråer i Finland visar att man oftast väljer det här sättet, eftersom det är svårt att hitta tidigare gjorda stycken som i frasering, tempo etc. precis skulle passa in i reklamfilmen. Den största utmaningen som reklammusiken ställs inför är att den skall fungera effektivt under den korta tid som reklamfilmen visas (jfr. Lindqvist \& Paltschik 1987: 6). Det är svårt att genom en musiksnutt på fem sekunder placera lyssnaren/tittaren mitt i öknen, storstaden eller urskogen, eller på detta lika korta intervall få henne att förstå att reklamfilmen handlar om kärlek, glädje eller fest. Detta är budskap som populärmusik i vanliga fall har tre till fyra minuter på sig att förmedla.

Med tidigare inspelad musik avses musik som spelats in för annat ändamål än att användas i film, TV eller TV-reklam (Fellows 1998: 13). Då man går in för att använda sig av tidigare kompositioner är det främst för att uppnå det som enligt Hurons kategorisering skulle vara targeting, dvs. rikta in sig på en speciell målgrupp genom att använda sig av ett musikstycke som associeras till en viss musikstil och levnadsstil. Likaså kan man skapa auktoritet genom att använda ett stycke av en känd artist.

Ett känt musikstycke underlättar även att man kommer ihåg reklamen och produkten bättre (Bjurström \& Lilliestam 1993: 71). Om en reklam förses med ett känt stycke, kommer detta stycke i framtiden att associeras till reklamen som det använts i. På så vis kan man förlänga reklamtiden för produkten även utanför själva reklamfilmen (Fellows 1998: 13) På detta sätt antas vi göra associationer till Levi’s jeans då vi hör låtar som Spaceman och The Joker, medan stycket We Are Family av Sister Sledge gör att vi associerar till Kappahl (i Sverige och Finland). I det här fallet associerar vi så starkt stycket med Kappahls kläder att man i de senaste reklamerna endast i slutklämmen, då Kappahls logo visas, behöver spela melodislingan - utan ord - till den ena 
takten som egentligen skulle bygga på orden "we are family". Vi vet att det är de välkända Kappahl kläderna vi presenteras för.

Enligt Lindqvists och Paltschiks (1987: 10) intervjuer anser de reklambyråfolk som gör reklamfilmer i Finland att det "visserligen kan vara en bra idé att använda välkända melodier i reklamen", men att det ofta är tekniskt nödvändigt att komponera ny musik, då det kan vara svårt att finna välkända melodier som har en sådan struktur att de fungerar på fem sekunder.

Då man använder tidigare gjorda kompositioner bör man först avgöra om det är ett visst stycke eller en viss inspelning, dvs. en viss version, av det stycket som är betydande för reklamfilmen. Reklambyrån skall enligt överenskommelse med copyrightägaren (kompositör, musikförlag etc.) köpa rättigheterna till att få publicera ett specifikt verk, vilket dock inte innefattar en specifik inspelning. För att få använda sig av en viss inspelning måste man köpa licensen för denna specifika inspelning. Om man på reklambyrån anser att det är stycket och inte originalartisten som är av vikt för reklamen, kan man alltså anlita någon, eventuellt förmånligare, artist att göra en coverinspelning av verket. Det här valet gör reklambyrån enligt behov, enligt vad syftet med användningen av detta stycke är. Ett instrumentalt stycke kan vara relativt lätt att reproducera. Även om man inte har tillgång till verkliga instrument eller levande musiker är det lätt att imitera stycket. Svårare är det däremot att imitera sång. I ett sjungen låt är artistens sångröst ofta av stor betydelse, därför kan det ofta vara viktigt att använda sig av originalinspelningen.

Om man vill rikta sig till en viss målgrupp genom användning av en viss genre, en viss musikstil eller ett visst "sound" finns även möjligheten att anlita en originalkompositör och beställa musik som låter som en viss artist eller grupp. På så vis skapar man en gruppkänsla hos den specifika målgruppen genom "soundet" av en känd artist, utan att behöva köpa licensen till ett känt stycke. Då man kopierar stilen eller soundet av en artist eller musikgenre talar man om sound-a-likes ${ }^{2}$ (jfr. Fellows 1998: 7; Bjurström \& Lilliestam 1993: 94).

Kim Kuusi, som är en av de mest anlitade reklammusikkompositörerna i Finland (Lindqvist \& Paltschik 1987: 12), säger att det blir allt vanligare att man som kompositör får en beställning på ett stycke som skall låta som en viss känd artist: 'I de mest patetiska fallen är det frågan om att man skulle vilja ha en viss låt. Därefter frågar man vad det kostar, får en hjärtinfarkt och begär någon annan komponera ett verk som påminner om originalinspelningen men ändå inte kan anklagas för plagiat." (Lamminen 2000; översatt av auktorn.)

"Library Music" eller produktionsmusik är det förmånligaste sättet att förse en reklamfilm med musik. I motsats till originalmusik komponerad för reklam är produktionsmusik inte komponerad för en viss reklam, utan för reklam i allmänhet med syftet att ge en viss stämning. Den är specifikt riktad till reklambyråer och produktionsbolag för att användas i reklamfilmer. Reklambyråer erbjuds CD:n som innehål- 
ler ett visst antal färdiginspelade stycken som oftast är 29 eller 59 sekunder långa, dvs. de vanligaste längderna på en reklam. (Fellows 1998: 17-18.) Låtarna är kategoriserade enligt stämningar, situationer eller saker de förväntas associeras till.

Produktionsmusik är ofta komponerad av samma kompositörer som även annars gör originalmusik till reklamfilmer. Skillnaden är alltså att de gör produktionsmusik utan att veta i vilket sammanhang den kommer att användas. Musiken köps upp av s.k. musik- eller produktionsbibliotek som i sin tur försöker sälja den vidare till reklambyråer.

\section{Olika typer av musikinslag}

Jingel är den företeelse som man oftast kopplar ihop med reklammusik. Det är även den form av reklammusik som, i motsats till bakgrundsmusik, är starkt profilerad just för att konsumenten skall lägga märke till den och komma ihåg den (Bjurström \& Lilliestam 1993: 80). Robynn J. Stilwell beskriver jingeln som: "En kort komposition gjord för att marknadsföra en produkt, oftast med sångtext, men ibland instrumental - - rimmande reklamtext med en melodisk 'hake' som lyssnaren lätt kommer ihåg, vilket gör att hon även kommer ihåg reklambudskapet ${ }^{33}$ ". Jinglar är skapade för att lätt identifieras med ett varumärke och är ofta en tonsatt form av ett varumärkes slogan.

Ett tydligt exempel på melodisatt slogan är den finska versionen av Felix matvaror, "Felix, Felix, herkkuja ruokapöytään", eller den internationellt använda "Gillette, the best a man can get". En längre form av jingel som egentligen kunde räknas som originalmusik med reklambudskap är "Menthos - the freshmaker", där reklammusiken utgörs av en längre låt bestående av vers och refräng.

Bakgrundsmusiken är den form av reklammusik som man oftast inte lägger märke till. I motsats till jingeln är den ofta svagt profilerad för att höras men inte dra till sig uppmärksamhet. Avsikten är inte att man skall minnas musiken eller melodin (Bjurström \& Lilliestam, 1993:82). Dess funktion är främst att skapa en positiv atmosfär kring produkten.

Då man i reklamfilmer använder tidigare inspelad musik, dvs. musik skriven för annat ändamål än reklam, är det ofta "klassisk musik" som man väljer för att ge rätt stämning åt reklamfilmen. Klassisk musik används främst då man vill ge reklamen en bild av exklusivitet, kvalitet, tidlöshet eller god smak (Bjurström \& Lilliestam 1993: 83).

I reklamfilmer för produkter riktade till ungdomar använder man sig sällan av klassisk musik. Reklamfilmen för dataspelet NHL 2000 skulle inte ge en bild av fartfylld spänning och "action" om den visades till musiken av Vivaldis Sommaren eller Edvard Griegs Morgonstämning. Däremot ackompanjeras de snabba ishockeyklippen av riffbaserad rockmusik spelad på distad elgitarr och drivande "up-tempo" trumtakt. 
Musiken kan jämföras med någon snabb låt av Van Halen eller Joe Satriani. Samma musikstil använder Eurosport som jingel då man visar bilder ur snabba sportgrenar som rally, Formel 1, fotboll, löpning etc. Philip Tagg (1979: 64) noterade över 20 år sedan att "Fuzz on electric gitarr, up-tempo rock drumming" förknippades med "modern, action, motor bike, speed" och exemplifierade detta med låten Easy Rider av Steppenwolf. Eftersom den här musiken, snart tjugofem år senare, ännu används i fartfyllda reklamfilmer riktade till ungdomar kan man se att distad gitarr och "up-tempo" trummor ännu idag förväntas förknippas med snabbhet, action etc.

Låten Easy Rider skulle enligt Niklas Rönnberg idag snarare förknippas med "retro", 70-tal och nostalgi än med "modern" (Rönnberg 1996: 12). För att ge en känsla av modernitet bör reklamfilmerna - inte alltför överraskande - ackompanjeras av musiktrender som är moderna idag.

I reklamfilmen för Philips CD-brännare som sändes på TV för ca. fem år sedan kunde man se en kille hemma i sin lägenhet spela in sin egen favorit-CD, i nästa scen går han fram till discjockeyn på en klubb och räcker över CD:n. Då musiken ändras från den tidigare mainstream discomusiken till Talvin Singhs Jaan från albumet Soundz of the Asian Underground (Talvin Singh 1997) stannar alla på dansgolvet upp förutom killen och en tjej som "hittar varandra" till tonerna av en något komplicerad drum'n'bass takt med asiatiskt låtande harmonier och sångstämma. Då reklamen gjordes var den här typen av musik en sorts riktgivare på den brittiska klubbmusikens topplistor. Reklamen försöker visa att man med hjälp av Phillips CD-brännare lätt kan spela in "det nyaste" som finns på musikmarknaden. Reklamen är i allra högsta grad riktad till ungdomar, då personerna som presenteras i filmen är unga och den utspelar sig på en dansklubb, en plats som symboliserar ungdomar. Eftersom det är en nyhet, något modernt man vill visa upp, behövs modern musik för att styrka trovärdigheten för hur modern produkten är. CD-brännaren hade högst antagligen kommit $i$ ett annat ljus om man visat reklamfilmen till tonerna av klassisk musik eller 70-tals rockmusik spelad på distade gitarrer. Musik som idag symboliserar modernitet är enligt Lilliestam stilar som techno, hip-hop, acid jazz etc. (Bjurström \& Lilliestam 1993: 85.) Men detta är trender som snabbt byts ut mot andra, vilket antagligen redan har skett - år 1997, då Talvin Singh gjorde Jaan var drum'n'bass ett relativt okänt begrepp. Musiken kan idag tolkas som en helt egen stil inom klubbmusik.

I sina reklamer för Pepsi Max presenterar Pepsi ungdomar som sysslar med extrema sporter såsom mountainbiking, rullskridskoåkning, paragliding etc. Musiken som ackompanjerar filmerna är sk. skatepunkmusik; distande gitarrkomp, "uptempo" trumkomp i betydligt snabbare tempo än 70-talets rockmusik. De symboliserar, liksom rockmusiken, fart och action. Man riktar sig till en - bland ungdomar - allmänt känd skate-livsstil som identifieras med något tufft och våghalsigt.

Då man använder sig av moderna trender inom reklammusiken bör man dock vara försiktig med att inte specialisera sig för mycket på en trend som riktar sig till 
en alltför specifik grupp individer och som då kan stöta bort den "stora skaran". Reklamen ska i det närmaste ändå attrahera en majoritet av konsumenterna. Man måste hitta en balansgång mellan att vara på nyhetstoppen och ändå tilltala den stora skalan.

\section{Klichéer och stereotyper}

I motsats till populärmusikstycken som har tre till fyra minuter på sig att förmedla budskap och känsla måste reklammusiken göra det direkt i inledningsfrasen. För att lyckas med detta används ofta samma klichéer som används inom filmmusik. Dessa klichéer kan kallas stereotyper av musikinslag inom filmmusik. Sådana klichéer kan vara exempelvis ett mollackord med stor septim spelat på en elgitarr, skulle ge ett hotfullt intryck. Samma ackord spelat på en harpa väcker enligt Tagg (1979: 65) däremot inte samma hotfulla stämning hos lyssnaren. Därmed kan vi konstatera att bl.a. instrumentvalet i vissa fall kan räknas som en kliché. En annan kliché kan även vara högt eller lågt tempo som ger TV-tittaren en känsla av fart eller lugn (jfr. Toivonen 1993: 46). Man vet att tittaren är van att höra dessa klichéer i filmsammanhang och sammankopplar dem med vissa sinnestämningar (Bjurström \& Lilliestam 1993). Då klichéer ur filmmusik förekommer i reklamfilmer, förväntar man sig att tittaren skall göra samma associationer som hon gjort då hon hört musiken i filmsammanhang.

På en högre nivå kan man konstatera att det förekommer större helheter av klichéer tagna ur filmmusiksammanhang, dvs. då tidigare nämnda klichéer "pusslas" ihop. Dessa kallar Tagg (1979: 64) stereotyper inom filmmusik, men de kan även vara stereotyper av musik i reklamfilmer. De här stereotyperna kan vara de olika typer av klassisk musik som jag redan nämnt och som utifrån Taggs forskning ger TV-tittaren associationer till klass, kvalitet, storhet, lyx etc. Gitarrbaserad rockmusik kan däremot förväntas ge en känsla av fart och action (Tagg 1979: 64). Technomusik, hip-hop, acid jazz etc. väcker däremot känslor av modernitet, något ungdomligt (Bjurström \& Lilliestam 1993: 85) Den drum'n'bass musik som Phillips använde sig av i sin reklamfilm valdes just för att ge bilden av att deras CD-brännare var något nytt och modernt. Då man således använder sig av klassisk musik, rock eller drum'n'bass är det musikstilarna som kan anses vara stereotyper av betydelsebildare för TV-reklamer.

En annan form av stereotyper i musik som Tagg (1999a: 13-14) har kommit fram till i sina undersökningar är hur lyssnaren uppfattar vissa stycken som maskulina och andra som feminina. De musikstycken som försökspersonerna ansåg vara maskulina hade typiska drag som snabbt tempo. Melodierna var ofta spelade i staccato, samt på elgitarr, gitarr, synt, trumpet eller xylofon. De ackompanjerades av gitarr eller brass, synthesizer och trummor. En faktor som han kallar det tonala språket utgjordes av rock eller jazz. 
De stycken som ansågs kvinnliga hade däremot ett lägre tempo. Melodierna spelades i legato på stränginstrument, flöjt, mandolin, oboe eller piano. De ackompanjerande instrumenten utgjordes av sträng- eller träblåsinstrument och piano. Ackompanjemanget skulle inte utgöras av brassinstrument eller trummor. Det tonala språket var i det feminina fallet klassisk musik (Tagg 1999a: 14).

\section{Undersökning}

För att mäta i hur stor grad tittarnas åsikter om produkten i en reklamfilm kan påverkas av musiken har jag valt att använda mig av en metod som Tagg (1999b) presenterar som hypotetisk substitution. Han har visat att hypotetisk substitution är en effektiv metod att mäta musikens vikt som betydelsebärare då den ackompanjerar filmer och TV-serier. Till samma filmsekvens byts musiken ut och därefter mäts betydelseförskjutningar. Eftersom bildsekvensen är densamma, kan man vara säker på att effekten ligger i musiken.

Med Taggs undersökning som grund vill jag undersöka musikens roll som betydelsebärare i TV-reklamer. Han har redan visat att musiken är kapabel att skapa särskilda stämningar åt en filmsekvens. I min undersökning skulle det här vara en reklamfilm. Jag ville dock föra undersökningen lite längre och testa om musiken, förutom att ge oss en helhetsstämning av reklamfilmen, direkt kunde hjälpa oss skapa en bild av produkten. För min undersökning använder jag mig av en en testgrupp (på tio personer). De får se samma reklamfilm tre gånger, varje gång med olika musikstycken som ackompanjemang. De musikstycken jag valt att använda överensstämmer med de musikstilar som enligt Tagg (1979: 64) och Bjurström och Lilliestam (1993: 85) förväntas ge särskilda stämningar till filmsekvenser respektive reklamfilmer:

Klassisk musik: stor, "klass", kvalitet, feminin

Rock musik byggd på gitarr-riff i snabbt tempo: fart, "action", maskulin

Drum'n'bass: modern, teknologisk

Efter varje visad reklamfilm frågar jag försökspersonerna vilken deras uppfattning om produkten är. Jag förväntar mig att de skall ha påverkats av musiken som ackompanjerar reklamfilmerna så att de gör samma associationer till produkten som de associationer som de stereotypa musikstilarna har konstaterats framkalla. 


\section{Visuellt undersökningsmaterial}

Som visuellt undersökningsmaterial har jag valt en reklamfilm bilen Peugeot 307, eftersom produkten (bilen) förekommer ensam utan att människor medverkar. Då personer medverkar i en reklamfilm ger oss dessa redan en uppfattning om vad det är för "sorts" människor som använder sig av produkten. Detta skulle kunna leda tittaren till att bilda en viss uppfattning om produkten, t.ex. "för män, för kvinnor, för rika snobbar, för friluftsmänniskor, för fartglada" etc. En annan viktig egenskap hos reklamfilmen är att den inte förses med varken ett uppläst eller skrivet budskap som berättar för oss vad som är speciellt med just den här produkten. Man låter istället bilder av produkten (bilen) tala för sig själv. Då man utesluter skrivna eller upplästa budskap är det endast bildsekvensen och musiken som påverkar hur tittaren uppfattar reklamfilmen och produkten, dvs. musikens betydelse som betydelsebildare kan konstateras vara större.

Reklamfilmen är inspelad på VHS band i Spanien i maj månad år 2001, då den sändes i de nationella TV-kanalerna som en del av reklamkampanjen för bilen. Mig veterligen har reklamfilmen inte sänts i nordiska TV-kanaler, dvs. försökspersonerna har inte sett filmen tidigare.

Reklamfilmen börjar med ett snabbt bildklipp över en ökenterräng, filmad med ett stenblock i förgrunden, en gestalt ses långt $\mathrm{i}$ bakgrunden gå fram genom ökensanden. Färgerna man använt är främst gul och ljusbrun, vilket ger en varm, något exotisk känsla. I nästa klipp ser man i närbild en kikare som brukar finnas vid turistutkiksplatser, den klassiska modellen som står på en rejäl pelarfot och ser ut som ett ansikte med två ögon, dvs. kikarlinserna man skall se genom. Kikaren avviker till färgen från resten av omgivningen, då den är skarpt gnistrande kromfärgad. Man ser att mannen som tidigare tog sig fram genom öknen tar tag i kikaren för att se genom den. Som ur kikarsynvinkel ser man två pyramider i öknen, och ett bergslandskap i bakgrunden. I följande sekvens ser man en bil på avstånd komma körande emot kameran. Den gnistrar till på samma sätt som kikaren tidigare gjort. Mannen, nu filmad underifrån, vänder blicken mot bilen. I nästa klipp ses bilen passera förbi bakom ett gräsfält och åter vända upp mot kameran. Mannen vänder kikaren mot bilen. En Peugeot 307 (det står 307 där nummerplåten skall sitta) ses köra allt närmare kameran.

I följande klipp ser man bilen passera förbi kikaren, som skymtar i förgrunden. Bakom bilen ses en sorts tavelram i storleken av en stor annonsskylt. Tavelramen innehåller samma landskap som det man ser runt tavelramen. Bilen, kikaren och tavelramen har samma kromade färg, medan landskapet runt dem fortfarande skiftar i brungult.

Nästa sekvens utgörs av en vit text på en svart bakgrund som lyder: "7 maravillas" (7 underverk). I nästa klipp ser man samma bil i slow motion passera på en smal väg omringad av en brant bergvägg och en skogsdunge. Den här gången skiftar bilden i 
blågrått. I bakgrunden ses en regnbåge. Det här klippet ger en mycket kallare, fuktigare stämning. Bilen filmas både framifrån och från sidan, då den passerar kameran.

I nästa klipp passerar bilen, fortfarande på en smal väg i ett bergigt, något ödsligt landskap, gråskiftande färger och en regnbåge i bakgrunden. Återigen visas en vit text mot svart bakgrund som lyder: "7 colores" (7 färger). Framför 7:an sätts sedan till 30, så att det slutliga budskapet blir "307 colores". Bilen filmas bakifrån, då den längs med samma ödsliga, smala väg kör vidare bort från kameran. I bakgrunden ser man broar och bergiga landskap som bilen skall färdas genom. Man kan ännu skymta regnbågen $\mathrm{i}$ bakgrunden.

En sista text (vit) på svart bakgrund lyder "307 Descubralo en su concesionario" (307 upptäck den hos din återförsäljare/generalagentur). Den åtföljs av logon, dvs. Peugeot-lejonet på en svart bakgrund.

Alla de olika, på varandra följande klippen utgörs av snabba byten, i realiteten hinner tittaren inte uppfatta alla de småsaker som händer i filmen. Det som torde fastna i tittarens minne är ökenlandskap, kromad kikare, Peugeot 307 och bergslandskap. Det är däremot den övergripande känslan av mystik som blir hängande i luften. Målet med reklamfilmen är att ge en gåtfull bild av bilen, då man inte besvarar frågor om motoreffekt, pris, säkerhet etc. Budskapet "upptäck den hos din försäljare" uppmanar kunden att själv ta reda på vad som är så speciellt med just den här bilen. Reklamfilmen är exakt 30 sekunder lång.

Peugeot 307 är i samma storleksklass som Volkswagen Golf, dvs. av mellanstorlek. Den är inte så starkt profilerad för vare sig män eller kvinnor. Den är ganska sportig, men ändå inte som t.ex. en BMW. Den är dock känd för att kunna fås i sportiga, snabbare versioner. I prisförhållanden befinner den sig i mellanklassen, aningen billigare än Golf och Audi A3, men dyrare än Opel, Hyundai etc. Sammanfattningsvis är den inte så starkt profilerad, vilket är viktigt för min undersökning. Det innebär att musiken kommer att spela en större roll för hur tittarna uppfattar bilen och dess egenskaper.

\section{Musikaliskt undersökningsmaterial}

Jag har försökt att välja musikstycken som är så "anonyma" som möjligt. Med det menar jag att de inte skall framföras av någon känd artist som kan ha en auktoritativ påverkan på budskapet, dvs. att produkten associeras till en viss artist och på så vis ge tittaren särskilda förväntningar på produkten utifrån artistens levnadsvanor eller "stil". Detsamma gäller kända klassiska eller populärmusikaliska stycken som kunde associeras till tidigare reklamfilmer, filmer eller TV-serier och på så vis påverka bilden av produkten utifrån tidigare associationer skapade till samma stycke. Det är således stycken där musikstil, inte artist eller känd melodi skall ha en avgörande roll. Lyssna- 
ren skall inte kunna göra kopplingar till artist, melodi eller reklamer, där stycket eventuellt tidigare använts istället för att skapa värderingar utifrån det musikaliska budskapet.

Jag har valt stycken som komponerats just för att skapa en speciell stämning. De musikstycken som jag valt återfinns på tre olika Library Music -skivor producerade av Sonoton, ett av de mest ansedda Library Music -företagen i världen ${ }^{4}$. De har alltså producerats enbart för att fungera som stämningsskapare och betydelsebildare i bl.a. radio- eller TV-reklam. Jag valde bland ca. 500 numrerade skivor ur Sonotons produktion ut tre musikstycken som jag ansåg kunde passa ihop med reklamfilmen i min undersökning. Mitt urval styrdes också av vilka stycken som jag ansåg kunde representera de stereotyper av musik jag ville använda mig av i min undersökning. Jag går då inte in på att i detalj analysera låtarna, utan använder främst styckenas helheter, dvs. melodier, harmonier, instrumentval och "sound" som indikatorer. Musik styckena vars påverkningsgrad jag valt att undersöka är:

1. Spacemaker komponerad av Nico Hertz på skivan Styling the Future (Nr. 281) som på skivomslaget beskrivs som: 'Upphetsande Drum'n'Bass som återspeglar dagens ungdom och innovation:Behagliga ljudbilder med hektisk drum'n'bass rytm."

Det här stycket kunde enligt Lilliestams forskning (Bjurström \& Lilliestam 1993: 85) associeras till modern, teknologisk, ny teknik etc. Jag förväntar mig att Spacemaker ska fungera som förmedlare av modern känsla på samma sätt som Talvin Singhs drum'n'bass stycke Jaan fungerade i reklamfilmen för Phillips CDbrännare.

2. Cross the Line från skivan Action and Sports 2 (Nr. 244), komponerad av Wesley Plass, Hannes Treiber och Marc Monsen. Stycket beskrivs som: "Styrkan av dagens pop och rock - tung hårdrock". Rockmusik spelad på elgitarr med trummkomp i snabbt tempo förväntas enligt Tagg (1979: 64) förmedla associationer som "modern", "action", "fart".

3. Year of Election från skivan Light and Dark (Nr. 307), komponerad av Gregor F. Narholz, beskrivs som: "Orkestrala teman baserade på kontrasten mellan det positiva och det negativa, det goda och det onda -- positiv, stolt, varm och inspirerande.”. Stycket kan jämföras med Theme from Emmerdale Farm som Tagg (1999a: 1) använt sig av i sin undersökning.

De tre musikstyckena kommer jag härefter att kategorisera som: Drum'n'bass, Rock och Klassisk. 


\section{Frågor}

Testgruppen utgjordes av tio personer i åldrarna 24-56 år. Sex av de deltagande var män och fyra av dem kvinnor. Två av de deltagande var över femtio år gamla, medan resten fördelade sig jämnt mellan 24 och 30 år. Personerna svarade skriftligen individuellt på frågorna i frågeformuläret. Efter den första reklamfilmen fick de i lugn och ro fylla i luckorna till påståendena och svara på de öppna frågorna. Då alla var klara, visade jag den andra reklamfilmen som de därefter fick svara på osv.

Frågeformuläret består i den första delen av slutna frågor, nämligen påståenden följda av en, av Arksey och Knight (1999: 92) kallad attitydskala, där testpersonerna skall fylla i till vilken grad de håller med påståendena. Försökspersonen skall därmed välja mellan alternativen: stämmer, stämmer inte helt och hållet, varken stämmer eller inte stämmer, stämmer väldigt lite, stämmer inte alls.

I den andra delen av frågeformuläret skall försökspersonen värdera bilen. Försökspersonerna ges sex prisalternativ av vilka de skall kryssa i den de anser bilen tillhöra. Alternativen är: 90-100 tusen mark, 101-110, 111-120, 121-130, 131-140 och 141150 tusen mark.

Den tredje delen av frågeformuläret består av två öppna frågor som försökspersonen fritt skall svara på. Frågorna lyder: Beskriv kort (ex franska streck, lösa ord) din uppfattning om bilens egenskaper, målgrupp(er) samt vilka associationer (kopplingar) du gör till bilen. Skriv ner allt som du kommer att tänka på! Är bilen i din smak? Är det här en bil du skulle vilja ha och köpa? Varför? Motivera!

Med de två olika frågetyperna, dvs. bundna frågor i form av attitydskalan samt öppna frågor, vill jag öka validiteten i resultaten som jag kommer fram till. De bundna frågorna "tvingar" försökspersonen att ta ställning till påståenden som hon nödvändigtvis inte skulle ha tänkt på, medan de öppna frågorna ger henne möjlighet att förtydliga sitt svar och ytterligare presentera tankar som reklamfilmen väckt hos henne.

\section{Resultat}

Eftersom det är ett medeltal av vad de tio personerna svarat som redovisas i tabellen vill jag betona att skalan går mellan 1-5, där ett högre tal betyder att försökspersonerna till högre grad har hållit med om att påståendet är riktigt. Tre poäng betyder att genomsnittet av personerna inte har tagit ställning till påståendet. Resultaten presenteras i följande tabell. Jag har vid varje påstående skuggat resultatet till den typ av musik som gav mest poäng: 


\begin{tabular}{|l|c|c|c|}
\hline Egenskaper & Drum 'n' bass & Rock & Klassiskt \\
\hline Familjebil & 1,8 & 1,1 & 3,5 \\
\hline För mannen i familjen & 3,8 & 4,4 & 3,1 \\
\hline För kvinnan i familjen & 3,6 & 2,4 & 4,2 \\
\hline Arbetsbil & 2,6 & 2,6 & 2,8 \\
\hline För ungdomar & 4,5 & 4,5 & 2,5 \\
\hline Shopping bil & 2,8 & 2,9 & 3,5 \\
\hline Bilen har en exklusiv design & 3,8 & 3,6 & 4,4 \\
\hline Bilen har en modern design & 4,8 & 4,3 & 4,2 \\
\hline Sportbil & 3,7 & 3,8 & 2,2 \\
\hline Bilen har en effektiv motor & 3,3 & 4,1 & 3 \\
\hline Bilen är krocksäker & 3 & 2,7 & 3,8 \\
\hline Bilen är billig & 2,1 & 2,4 & 1,9 \\
\hline Bilen är dyr & 4 & 3,7 & 4 \\
\hline Bilen är bra i svår terräng & 2,8 & 2,7 & 2,6 \\
\hline Bilen är rymlig & 2,2 & 2,5 & 3,3 \\
\hline Statusbil & 3,3 & 2,8 & 3,7 \\
\hline Bilen är snabb på motorvägen & 4 & 4 & 3,4 \\
\hline Bilen är smidig i stan & 4,1 & 3,9 & 4,2 \\
\hline Bilen är av hög kvalitet & 4,3 & 3,9 & 4,5 \\
\hline
\end{tabular}

Av tabellen framgår att försökspersonerna inte direkt såg Peugeot 307:an som en familjebil. Det påståendet fick endast 1,8 poäng, varvid det närmaste svarsalternativet är "stämmer inte helt och hållet" ( 2 poäng). De ansåg att bilen var ungefär lika mycket för mannen som för kvinnan i familjen. De båda påståendena fick 3,8 respektive 3,6 poäng. Påståendet "arbetsbil" fick 2,6 poäng, medan bilen till hög grad ansågs vara för ungdomar. Det påståendet fick 4,5 poäng. "Shoppingbil" fick 2,8 poäng, vilket ligger ganska nära det neutrala 3 poäng. Bilen ansågs ha en relativt exklusiv design, då det påståendet fick 3,8 poäng. På påståendet "bilen har en modern design" blev det genomsnittliga talet 4,8 , vilket betyder att majoriteten tyckte att det här påstående stämde. Påståendet "sportbil" ansågs stämma ganska bra då poängen blev 3,7. Lite lägre poäng, 3,3, fick bilen för påståendet att den skulle ha en effektiv motor. Krocksäkerhet tog genomsnittet av försökspersonerna inte ställning till. Det påståendet fick jämna 3 poäng. Den ansågs inte direkt vara billig, utan ganska dyr. De påståendena fick 2,1 respektive 4 poäng. På 2,8 poäng, ganska nära det neutrala tre, kom påståen- 
det att bilen skulle vara bra i svår terräng. Drum'n'bass musiken fick lägst poäng av alla tre musikstilar $(2,2)$, då påståendet löd "rymlig". Som statusbil kom den upp till 3,3 , medan dess snabbhet på motorvägen nådde upp till fyra poäng, dvs. exakt "stämmer ganska mycket". Ännu högre poäng tog den på "smidig i stan" (4,1 poäng) samt "av hög kvalitet" (4,3 poäng).

Rockmusik som ackompanjemang till reklamfilmen bidrog till att försökspersonerna inte alls tyckte Peugeot 307:an var en familjebil. Poängen landade på 1,1. Däremot ansåg de att bilen till hög grad var ämnad för mannen i familjen (4,4 poäng), medan den inte ansågs vara för kvinnan ( 2,4 poäng). Som arbetsbil tog den samma poäng som drum'n'bass musik, dvs. 2,6. Även ifråga om påståendet att bilen var för ungdomar tog den lika många poäng som vid ackompanjemanget av drum'n'bass, dvs. 4,5 poäng.

Påståendet "shopping bil" tog man däremot inte stark ställning till. Det påståendet fick 2,9 poäng. "Exklusiv design" och "modern design" fick 3,6 respektive 4,3 poäng. Påståendet "sportbil" tog högsta poäng av de tre musikstilarna då reklamfilmen ackompanjerades av rockmusik. Den nådde då upp till 3,8 poäng. Likaså var fallet då påståendet löd "bilen har en effektiv motor". I det fallet ansåg försökspersonerna att påståendet stämde ganska bra (4,1 poäng). Av de tre musikstilarna bidrog rockmusik till att bilen ansågs vara minst krocksäker ( 2,7 poäng). Den ansågs i det fallet även vara billigast (2,4 poäng). Den ansågs inte heller vara lika dyr som då musiken vara drum'n'bass eller klassisk, utan stannade strax efter de andra två (3,7 poäng). Ganska nära det neutrala blev poängen 2,7 , då påståendet löd "bra i svår terräng". Lite lägre (2,5 poäng) då påståendet löd "bilen är rymlig". Påståendet statusbil fick 2,8 poäng. Försökspersonerna ansåg att påståendet "snabb på motorvägen" stämde ganska bra, dvs. poängen blev jämnt 4 , vilket var lika mycket som då reklamfilmen ackompanjerades av drum'n'bass. Nästan lika mycket poäng, 3,9, fick den då påståendet löd "smidig i stan", vilket även var fallet då det löd "bilen är av hög kvalitet".

Då försökspersonerna hörde klassisk musik när de såg reklamfilmen ansåg de att bilen till betydligt högre grad var en familjebil. De genomsnittliga poängen blev då 3,5. Som bilen för mannen fick klassisk musik de sämsta poängen, dvs. 3,1. Den ansågs i betydligt högre grad passa kvinnan, då poängen blev 4,2. Som arbetsbil fick den 2,8 poäng.

Av de tre musikstilarna fick klassisk musik minst poäng, närmare bestämt 2,5, då påståendet löd "för ungdomar". Som shoppingbil fick den däremot mest poäng, liksom då påståendet löd "exklusiv design". Poängen blev i de fallen 3,5 respektive 4,4. Påståendet "bilen har en modern design" fick däremot lägsta poäng: 4,2. Likaså fick den lägsta poäng, då påståendet löd "sportbil" poängen endast blev 2,2. Även motorn ansågs minst effektiv. Det påståendet fick neutrala 3 poäng.

Krocksäkrast ansågs bilen vara då reklamfilmen ackompanjerades av klassisk musik. Det påståendet fick 3,8 poäng. Försökspersonerna höll inte med om att den var bil- 
lig då de genomsnittliga poängen blev 1,9. Bilen ansågs dock vara lika dyr som när reklamfilmen ackompanjerades av drum 'n' bass. Påståendet fick då samma 4 poäng. Bilen ansågs klara sig sämst i svår terräng (2,6 poäng). Den ansågs dock med 3,3 poäng vara rymligast samt till högre grad vara en statusbil än då annan musik användes. Den kom i det fallet upp till 3,7 poäng. Bilen ansågs vara långsammast på motorvägen, med 3,4 poäng. Klassisk musik tog däremot hem största poängen vad gällde "smidig i stan", med 4,2 poäng samt "bilen är av hög kvalitet som nådde upp till hela 4,5 poäng.

I den andra frågan i frågeformuläret uppmanades försökspersonerna att placera in bilen i den prisklass som de ansåg den höra hemma. Musiken verkade i det här fallet inte ha så stor inverkan på hur personerna svarade. I alla fall utom ett svarade försökspersonerna samma på frågan, dvs. 111.000-120.000 mk. Endast en person kryssade i en klass billigare, 101.000-110.000 mk, då reklamfilmen ackompanjerades av rockmusik.

Då reklamfilmen ackompanjerades av drum'n'bass-musik svarade två av försökspersonerna att Peugeot 307:an passade bäst för unga män, medan en person svarade att den passade den moderna kvinnan. En person ansåg att den passade för ensamstående, en att den passade för ungdomar och en att den passade för ett ungt par. Ett svar ljöd "övre medelklass".

Inom kategorin egenskaper svarade fem personer att bilen var smidig. En person tyckte den var "relativt liten" och en ansåg att den var tyst. Två personer bedömde den som snabb, medan tre personer ansåg den vara tuff. En person kallade bilen för sportig och två personer ansåg den verka lättmanövrerad. En person ansåg sig veta att den var bränslesnål och två personer tyckte att den inte passade som vinterbil.

Den tredje gruppen av svar utgörs av uttryck som har med användningsmiljö att göra. Då drum'n'bass-musik ackompanjerade reklamfilmen ansåg tre personer att bilen var en storstadsbil. Tre av försökspersonerna uppfattade att den inte var passande för långfärder, medan tre av dem betonade att den inte var bra i terräng.

Då reklamfilmen ackompanjerades av rockmusik noterade fyra personer att bilen var passande för ungdomar. En person ansåg att den skulle passa mannen. En person klassificerade bilen som cool, medan tre tyckte att den var snabb. En av försökspersonerna ansåg att den var smidig och en att den var stark. Bra väghållning poängterade en person, medan en betonade att den var lättmanövrerad. Sex personer ansåg att bilen var tuff. En person tyckte att den var liten, medan en däremot beskrev den som stor. Enligt tre personer var bilen välutrustad med stereo och lädersäten. En person klassificerade den som pigg, medan två personer uppfattade den som sportig.

I fråga om användningsmiljö ansåg två personer att bilen fungerade bra i terräng och två att den skulle passa bra för landsbygden. Enligt två av försökspersonerna hörde bilen hemma i storstadsmiljö.

Då reklamfilmen ackompanjerades av klassisk musik ansåg en försöksperson att bilen skulle passa bra som andra bil. Enligt tre personer passade den bättre för vuxna 
och äldre människor. Tre personer betonade att den skulle den vara bra för "den lilla familjen" medan två ansåg att den främst passar kvinnan. En person konstaterade att den var passande för intellektuella, medan en ansåg den passa bra för lugna förare.

Inom kategorin adjektiv eller egenskaper blev svarsresultaten följande: En person tyckte att bilen löpte tyst. Valet av klassisk musik bidrog till att två personer uppfattade bilen som smidig. Tre personer tyckte bilen var liten, medan två ansåg den vara rymlig. En person konstaterade att bilen hade en "glidande känsla" och en tyckte att den verkade lättmanövrerad. Bilen ansågs av en person vara elegant och av en sensuell. En person tyckte den var enkel och en att den utstrålade kvalitet. Två personer poängterade att den kändes dyr och två att den kändes säker. "Komfort" beskrev en person bilen med, medan tre personer ansåg att den skulle vara passande för "cruising".

Vid valet av användningsmiljö betonade två personer att bilen gjorde sig bra som stadsbil, medan en person ansåg att den var passande för landsvägskörning.

På frågan om man skulle vilja köpa bilen eller inte svarade fem personer då de hört reklamfilmen ackompanjerad av drum'n'bass ansåg att bilen var i deras smak och att de gärna skulle köpa den. Tre av försökspersonerna tyckte att de gärna skulle ha en Peugeot 307:a, men att den inte skulle vara deras första val. Bilen föll inte alls i tycket för en person, varför hon heller inte skulle köpa den.

Då reklamfilmen ackompanjerades av rock musik ansåg åtta av försökspersonerna att bilen var i deras smak och att de gärna skulle köpa den. Två personer skulle däremot inte vilja köpa den, eftersom den inte var i deras smak.

Klassisk musik som ackompanjerande musik till reklamfilmen gav en jämnare fördelning mellan svarskategorierna. Tre av försökspersonerna ansåg att de gärna skulle köpa bilen. Fyra personer ansåg att den inte skulle vara deras första val och tre att den inte alls passade deras smak.

\section{Sammanfattning av resultaten}

Det kan fastställas att konsumentens uppfattning om en produkt kan förändras till en följd av att musiken i reklamfilmen byts ut mot annan musik. Musiken kan påverka hur konsumenten uppfattar en produkt, dess egenskaper och materiella värde. Man kan genom att välja musik ur en särskild genre, ett visst sound eller tempo spelad på olika instrument styra hur konsumenterna uppfattar produktens egenskaper. Hypotetisk substitution visade sig vara en fungerande metod för att mäta dessa betydelseförskjutningar.

Produkten positioneras med hjälp av musiken, vilket betyder att man förser den med associationer till olika egenskaper den förväntas ha och till målgrupper den anses vara ämnad. Då konsumenten identifierar sig själv med den här gruppen och iden- 
tifierar produkten med den smak hon själv har, kan hon påverkas att välja den här produkten framom en annan.

Musiken verkar däremot inte i den här reklamfilmen kunna påverka till vilken mån en produkt värderas i pengar. Detta kunde åtminstone inte påvisas i den för det här arbetet gjorda undersökningen. Den här värderingen verkar mer styras av marknadspriser som bilförsäljare satt upp. Man följer dessa priser och låter sig inte påverkas av vilken image - billigare eller dyrare, högre eller lägre klass - man personligen anser att bilen har.

Peugeot 307 passar enligt försökspersonerna både den unga mannen och den moderna kvinnan. Då Tagg (1999a: 14) kategoriserar feminin och maskulin musik passar drum'n'bass inte klart in i någondera kategori. Försökspersonerna har inte heller ansett att bilen passar bättre för varken mannen eller kvinnan. Överlag anses bilen vara riktad till ungdomar och har en modern design. Enligt Bjurström och Lilliestam (1993: 85) används den typen av musik då en reklamfilm skall uppfattas som modern. Drum'n'bass-musik kan anses vara den mest moderna och teknologiska musiken av de tre jag använde. Den är spelad på synthar och har en modern karaktär._Därför antog jag att den även skulle få mest poäng då påståendet löd: "för ungdomar". Vid det här påståendet uppnådde dock även rockmusiken samma resultat. Rockmusik kan tydligen än idag ses som ungdomlig då det gäller bilar och motorer, liksom Philip Tagg (1979: 64) konstaterade att den gjorde redan vid slutet av 70-talet. Bilen anses även vara smidig och snabb vilket kan ha orskats av det snabba tempot som stycket har (jfr. Toivonen 1993: 46). Det i sin tur ger väl också en känsla av ungdomlighet.

Bilen är, enligt testgruppen, inte ämnad för terräng och är inte en bra vinterbil. Den gör sig bäst i storstadsmiljö. Detta beror antagligen på att drum'n'bass är en musikstil man snarare sammankopplar med storstadsliv och klubbar än landsbyggd och naturliv. Tittarna påverkas av musiken och har därför svårt att placera in bilen $i$ en svår terräng då det är musik som hör stadsliv till som spelas i bakgrunden.

Bilen passar främst ungdomar, eftersom den är snabb, sportig och har en effektiv motor. Det här kan avspegla sig på det som Tagg (1979: 64) påvisar att rockmusik ger en känsla av fart "action" och modern. På den musematiska nivån kan man konstatera att det är det snabba tempot i låten som ger en känsla av fart, snabbhet och därav effektiv motor (jfr. Toivonen 1993: 46). Det här anses klart vara en bil för mannen, inte för kvinnan. Musikstycket passar precis in i Taggs kategorisering av feminin och maskulin musik (Tagg 1999a: 14). Jämförelsevis bör nämnas att liknande musik användes i reklamfilmerna för NHL-spelet och Pepsi Max, med ishockey respektive extrem sport som tema. Båda är typiska manliga sporter. Peugeot 307 anses klara sig lika bra i svår terräng på landsbygden som i stadsmiljö. Orsaken till det här resonemanget kan bero på att denna typ av musik ofta används för att ackompanjera reportage om motorsport där tävlingarna ofta utspelar sig i svår terräng. Då försökspersonerna hör liknande musik ackompanjera reklamfilmen förknippar de bilen med dessa 
motorsporter. Dessa associationer har uppstått på nivån musical movement eller work, där musikstycken och - genrer fungerar som betydelsebildare (jfr. Tagg 1979: 78) Både drum'n'bass och rockmusik gav en känsla av fartfylldhet vilket ofta - oavsett individuella körvanor - förknippas med något ungdomligt.

Man hade kunnat förvänta sig att bilen, ackompanjerad av rockmusik, skulle ha ansetts vara snabbast på motorvägen, eftersom Tagg poängterat att den här typen av musik oftast förknippas med "action", "speed" etc. (Tagg 1979: 64). Drum'n'bass musiken gav dock samma resultat. Det kan bero på att även det stycket har ett snabbt tempo (jfr. Toivonen 1993: 46). Då reklamfilmen ackompanjerades av drum'n'bass och rock som båda har ett snabbt tempo, gav det en känsla av att bilen rörde sig snabbare på TV-skärmen än då reklamfilmen ackompanjerades av klassisk musik ${ }^{5}$. Man kan även anta att försökspersonerna uppfattar drum'n'bass musiken som mest teknologisk och att den därmed kan ha gett känslan av att bilen byggde på en modern teknologi (jfr. Bjurström \& Lilliestam 1993: 85) och utvecklad effektivitet, vilket leder till snabbhet på motorvägen. Påståendet "utvecklad teknologi" är ett påstående som jag gärna kunde ha tagit med i frågeformuläret.

Sportigast ansågs bilen vara då reklamfilmen ackompanjerades rockmusik, vilket kan antas gå hand i hand med begreppet effektiv motor. På TV-kanalen Eurosport används ofta fartfylld rockmusik som ackompanjemang till motorsportreportage. Det är möjligt att försökspersonerna har påverkats av den här typen av TV-sändningar och därför relaterar rockmusik till bilsport. Man kan isåfall konstatera att det tydligt är den audiovisuella inlärningsprocessen som påverkat dem (jfr. Tagg 1979: 64).

Skillnaden mellan poängen som drum'n'bass och rockmusik fick i sportbilskategorin var dock inte stor. Ett argument kunde då vara att det är bilens design, dvs. utseende, som påverkar hur sportig bilen uppfattas. Designen som tittarna uppfattat genom det visuella budskapet i reklamfilmen kan i det här fallet anses påverka tittarna starkare än valet av musik. Det här argumentet håller emellertid inte, eftersom bilen inte ansågs särskilt sportig ackompanjerad av klassisk musik. Förutom det klassiska soundet kan det då även vara det lägre tempot i stycket som ger en mindre sportkänsla.

Åtta av tio personer ansåg vid ackompanjemang av rockmusik att den här bilens egenskaper motsvarade de egenskaper de söker hos bilen de vill ha och att de gärna skulle köpa den. Tittarna ansåg sig alltså behöva en ungdomlig bil som klarar sig bra i svårare terräng.

Då klassisk musik ackompanjerade reklamfilmen ansåg försökspersonerna att Peugeot 307 är en familjebil. Trots att den känns rymlig är den dock inte tillräckligt rymlig för en större familj. Rymligheten kan jämföras med Taggs (1979: 64) teori att klassisk musik ger en känsla av stor. Musiken har dock inte helt och hållet lyckats överrösta det visuella budskapet att bilen skulle vara stor. Antagligen är det den krocksäkerhet den utstrålar som får den att kännas som en familjebil. Den anses vara mer 
passande för människor med en lugn körstil vilket kan bero på det lugna tempo som låten spelas i (jfr. Toivonen 1993: 46) Bilen anses vara mer passande för äldre människor än för ungdomar. Detta kan avspegla sig på Taggs (1979: 64) teori att klassisk musik associeras till förfluten tid samt på resonemanget lugn körstil; äldre människor kan uppfattas ha en lugnare körstil än ungdomar. Av samma orsak ansågs den passa bättre för människor som vill "glida fram" eller "cruisa omkring" i staden eller på landsvägen. Den passar även kvinnan bättre än mannen vilket var väntat utifrån Taggs (1999a: 14) kategorisering av maskulin och feminin musik. Bilen anses överlag exklusiv. Den är av hög kvalitet och kan t.o.m. kallas en statusbil. Dessa tre konstateranden kan bero på de associationer som Tagg (1979: 64) påvisar att klassisk musik ger, nämligen klass och kvalitet.

Som avslutande kommentar bör även sägas att musiken inte ensam kan styra tittarnas uppfattning av bilen. Bilens design och tittarnas tidigare förutfattade meningar om t.ex. bilmärket Peugeot samt modellen 307 spelar en stor roll i hur de ser på bilen. Med musikens hjälp kan reklamproducenten dock betona eller förvränga egenskaper de vill få fram om bilen för att presentera den på ett så fördelaktigt sätt som möjligt. Enligt denna undersökning är det rockmusiken som skulle ge den här bilen mest antal potentiella köpare.

\section{Referenserna}

1 Stycket användes år 1968 av Stanley Kubrick som signaturmelodi till filmen 2001: A Space Odyssey.

2 Sound-alike är en inspelning som imiterar en stil som är unik för en artist. Ifall man inte har utförligt lov av upphovsmannen, bör sound-alikes undvikas. - - Det är ofta originalartisten som vunnit i rättegångar om fall där sound-alikes använts. (http://www.signature-sound.com/11 quest.html\#q8, (11.04. 2002)

3 (New Grove's Music Dictionarys online uppslagsverk på webadressen: www.grovemusic. com, 14.04.2002)

4 Sonotons samling består hittills av över 600 CD. Varje år ger de ut omkring 30 nya. På deras websida www.sonoton.com kan man välja mellan 40000 musikstycken som man kan lyssna på och ladda ner.

5 Förutom för de tio försökspersonerna i testgruppen visade jag även de tre filmerna för eleverna i årskurs sju. Eleverna konstaterade att bilen verkade röra sig långsammare då reklamfilmen ackompanjerades av klassisk musik.

\section{Källor}

\section{FONOGRAM}

Styling the Future (Sonoton SCD 281).

Light and Dark (Sonoton SCD 307).

Action and Sports 2 (Sonoton SCD 244). 


\section{LITTERATUR}

Arksey, Hilary \& Knight, Peter (1999) Interviewing for Social Scientists. London: SAGE Publications.

Bjurström, Erling \& Lilliestam, Lars (1993) Sälj det i toner, Om musik i TV-reklam. Stockholm: Konsumentverket.

Cook, Nicholas (1994) "Music and meaning in the Commercials" Popular Music vol. 13/1.

Fellows, Joanne (1998) Acquiring Music for Television Commercials. An Investigation into a Neglected Section of the Music Industry. http://www.theblackbook.net/acad/tagg/ studtxts.html (2002-04-18)

Huron, David (1989) "Music In Advertising, An Analytical Paradigm ". Musical Quarterly, vol. 73, nr. 4, sid. 557-574. http://www.music-cog.ohio-state.edu/Huron/Publications/ huron.advertising.text.html (18.04.2002)

Lamminen, Maria (2000) "Tää mainoshan kuulostaa aivan..." Helsingin Sanomat "Klick!" 21.07.2000. http://www.helsinginsanomat.fi/klik/arkisto/2000heinakuu/20000721 klik74mainosmusa2.html (18.04.2002)

Lindqvist, Lars-Johan \& Paltschik, Mikael (1987) Musik i reklam. Jyväskylä: University of Jyväskylä.

Meyer, Leonard B. (1956) Emotion and Meaning in Music. Chicago \& London: The University of Chicago Press.

Middleton, Richard (1990) Studying Popular Music. Milton Keynes \& Philadelphia: Open University Press.

Rönnberg, Niklas (1996) Musik som extra uttryck, en explorativ studie av filmkompositörers arbetssätt och syn på filmmusiken. C-Uppsats Ht 96, Tema Kommunikation, Medierna och samhället. Linköping: Linköpings Universitet.

Tagg, Philip (1979) Kojak. 50 seconds of Television Music: toward the Analysis of Affect in Popular Music. Skrifter från Musikvetenskapliga Institutionen. Göteborg: Göteborgs Universitet.

Tagg, Philip (1994) "Subjectivity and Soundscapes, Motorbikes and Music". Essays on Vroom and Moo. Edited by Helmi Järviluoma. Department of Folk Tradition. 48-66: Tammerfors. http://www.theblackbook.net/acad/tagg/texts.html (18.04.2002)

Tagg, Philip (1999a) Music, Moving Image, Semiotics and the Democratic Right to Know. http://www.theblackbook.net/acad/tagg/texts.html (18.04.2002)

Tagg, Philip (1999b) TV Music: Quick Fixes, Semiotics and the democratic right to know. http://www.theblackbook.net/acad/tagg/texts.html (18.04.2002)

Toivonen, Maarika (1993) "TV-mainosten miehet ja naiset, Mainosmusiikin käyttö sosiaalisen viestinnän välineenä”. Etnomusikologian vuosikirja 5. Helsinki: Suomen etnomusikologinen seura. 